OPINIÃO

\title{
A taxa de juros? Trata-se de uma decisão técnica
}

Marcio José Vargas da Cruz*

“A taxa de juros? Trata-se de uma decisão técnica!" Que bom, assim podemos ficar mais tranqüilos! Disse o pai, que havia convivido com um doloroso processo inflacionário ao longo de anos, ao ler a notícia ao filho, que todavia se familiarizava com terminologias pouco questionadas por aqueles que estão em sua volta.

"Mas afinal, o que é uma decisão técnica?" - perguntou o filho. "Segundo o dicionário, a palavra técnica refere-se ao conjunto de processos de uma arte, ou então, maneira, jeito ou habilidade especial de executar ou fazer algo. Meu filho, isto quer dizer que a decisão para a meta da Taxa Selic (taxa média dos financiamentos diários, com lastro em títulos federais, apurados no Sistema Especial de Liquidação e Custódia), ou seja, a referência para a taxa básica de juros da economia brasileira foi decidida pelo Comitê de Política Monetária - COPOM, sem que houvesse influências políticas, as quais poderiam distanciar de seu objetivo de colaborar com a estabilidade do nível geral de preços desta economia" respondeu o pai. "Ah! Agora entendi!"- disse o filho, aliviado. Não que ele tivesse compreendido a frase de seu pai em sua plenitude, mas ao menos havia absorvido a idéia de que o processo de decisão era confiável. Na realidade, a única parte da frase que lhe chamou a atenção, sendo suficiente para a interpretação acima foi o fato do pai ter lhe dito que não houve influências políticas nesta decisão. Sendo o filho um observador atento ao comportamento de diversos políticos, a correlação foi imediata.

Ao longo de algum tempo, o termo "decisão técnica" tem sido utilizado diversas vezes com um intuito próximo ao das empresas que lançam um produto e colocam um especialista da área para dizer, é comprovado cientificamente. Ou seja, tenta-se passar a mensagem de que foram utilizados procedimentos nos testes que tornam inquestionáveis a validade deste produto, ou neste caso, desta decisão.

Existem dois pontos importantes nesta questão que merecem observação. Primeiramente, o fato da taxa SELIC ser determinada a partir de uma "decisão técnica", por parte do COPOM, restringe razoavelmente a possibilidade de interferências políticas explícitas, por parte do governante maior da república, que não convirjam com o objetivo de

\footnotetext{
* Professor do Departamento de Economia da Universidade Federal do Paraná. Endereço eletrônico: marciocruz@,ufpr.br
} 
se manter a estabilidade do nível geral de preços da economia. É extremamente positivo, saber que o COPOM terá como referência em sua decisão, procedimentos que lhe garanta uma relativa transparência, ou seja, a utilização de técnicas e instrumentos que lhes auxiliem no processo de decisão, frente a um objetivo previamente estabelecido. Contudo, isto não quer dizer que aqueles que tomam a decisão, ou até mesmo, definem os instrumentos ou a técnica a ser utilizada no processo sejam desprovidos de formação ideológica, relações políticas e valores morais, que venham a influenciar sua deliberação, mesmo se tratando de alguém com um inquestionável comportamento ético, como se espera daqueles que ocupam estes cargos na sociedade.

Outra questão relevante refere-se ao fato de que os instrumentos, ou a técnica, a ser utilizada no processo, ainda que esteja parcialmente adequada, pode apresentar falhas em suas premissas iniciais ou em sua estrutura, que podem comprometer a decisão e conseqüentemente o objetivo que este persegue, neste caso, a meta estabelecida para a taxa de inflação. Aliás, cabe ressaltar que estes problemas também estão implícitos na decisão da própria meta.

Apesar de evidentes, estas observações têm apenas o intuito de ajudar àquele pai em prosseguir com a explicação para o filho, sem interesse de levantar qualquer suspeita quanto às "decisões técnicas". Possivelmente, ao observar o crescimento pífio da economia brasileira nos últimos anos, compará-lo com o de outros países em desenvolvimento mundo afora, estudar um pouco política monetária e se deparar com as dificuldades enfrentadas por ele e pelos demais colegas para encontrar um emprego, provavelmente o filho dirá: "É pai, com relação à taxa de juros, de fato trata-se de uma decisão eminentemente técnica, com todos os problemas que ela envolve em sua análise custo-benefício, sem que esteja desprovida dos riscos de erros inerentes ao processo decisório e nada mais". Porém, é sempre bom lembrar, trata-se de uma "decisão técnica".

160 